Fundamental Electronic Library "Russian Literature and Folklore". URL: http://feb-web.ru/feb/ushakov/ush-abc/19/us466710.htm? cmd=0\&istext=1 [in Russian].

12. Frantova, T. (2014). Studying the scientific heritage of composers as an urgent task of modern musicology. Basic research. No. 12. pp. 258-262 [in Russian].

13. Epshtein, M. (2016). From knowledge to creativity. How the Humanities Can Change the World. Moscow; St. Petersburg: Center for Humanitarian Initiatives [in Russian].

УДК 78.071.1(477)(092):785.03

DOI https://doi.org/10.31723/2524-0447-2020-31-2-12

Ганна Серхї̈вна Савченко

ORCID: 0000-0002-9845-0450

кандидат мистецтвознавства, доцент, доцент кафедри композииії та інструментування Харківського національного університету мистецтв імені I. П. Котляревського lanna2@ukr.net

\title{
ПРИЙОМИ ВТІЛЕННЯ ПЛАСТИЧНОСТІ ЯК «УНІВЕРСАЛІЇ» ОРКЕСТРОВОГО МИСЛЕННЯ I. СТРАВІНСЬКОГО (НА ПРИКЛАДІ «КОНЦЕРТНИХ ТАНЦІВ» ТА «БАЛЕТНИХ СЦЕН»)
}

Мета роботи - систематизація оркестрових прийомів реалізації пластичності як однієї з універсалій оркестрового мислення I. Стравінського та принципу його оркестрового письма. Методологія дослідження. У роботі автор спирається на аналітичний, функиіональний, компаративний методи дослідження. Наукова новизна полягає в тому, що вперше в українському музикознавстві оркестрове письмо I. Стравінського досліджується в аспекті виявлення якісних характеристик пластичності й технічних прийомів його втілення. Висновки. У статті пластичність трактується як одна з «універсалій» (С. Савенко) оркестрового мислення I. Стравінського (разом із багатофігурністю та комбінаторністю), а також як властивість (якісна характеристика) його оркестрового письма. Під пластичністю розуміємо такі власти-

(C) Савченко Г. С., 2020 
вості оркестрової тканини, які (за Н. Коляденко та А. Шмельковою) активізують синестетичне сприйняття із задіянням візуальних та кінестетичних праобразів: формують виразні відчуття руху (різноспрямованого), об'єму (різновеликого і різнонаповненого), пластики ліній, різноякісної щільності (згущення-розрідження), відокремленості елементів оркестрової тканини, просторовості. На нашу думку, в оркестровій тканині пластичність виявляється в діалектичній єдності протилежностей: вона передбачає одночасно ясність, оформленість, опуклість, гнучкість та «перехідність» (статичність та процесуальність). Як принцип оркестрового письма пластичність взаємодіє із принципами багатофігурності та комбінаторності. Аналіз партитур «Балетних сцен» $i$ «Кониертних танців» продемонстрував, що втілення пластичності відбувається завдяки комплексу взаємопов'язаних оркестрових прийомів: гнучкості тембрових передач фігур; рухливості, ритмо-мелодійній виразності басу; застосування різнофункціональних фігур (складної конфігурації, різноспрямованого руху, кружляння, обертання, закруглених); фрагментарним дублюванням-підсвіткам, гетерофонному розщепленню ліній фактури.

Ключові слова: I. Стравінський, пластичність, таниювальність, оркестрове письмо, оркестрова тканина, рух, просторовість, щільність.

Savchenko Hanna Serhiivna, Candidate of Art Criticism (Ph. D. in Musicology), Associate Professor, Associate Professor at the Composition and Instrumentation Department of the Kharkiv National I. P. Kotlyarevsky University of Arts

Ways of incarnating of plastique as a "universal" of I. Stravinsky's orchestral thinking (on example of "Danses Concertantes" and "Scenes de Ballet")

The aim of the research is to systemize orchestral principles through which plastique is incarnated as one of the "universals" of I. Stravinsky's orchestral thinking and as a principle of his orchestral writing. The author relies on such methods of research as analytical, functional and comparative. The scientific novelty of the article lies in the fact that for the first time in Ukrainian musicology I. Stravinsky's orchestral writing is examined in aspect of plastique, its characteristics and ways of embodiment. Conclusions. In the given article we understand plastique as one of the "universals" (in the terms of S. Savenko) of I. Stravinsky's orchestral thinking (alongside multi-figure and combinatorics) and as a qualitative characteristic of his orchestral writing. We define plastique as the elements of orchestral texture, which (according to $N$. Koliadenko and A. Shmelkova) call for synaesthetic reception, founded on visual and kinaesthetic images: they create expressive sensation of movement (in different directions), volume (of different amount and content), graphic expression of the lines, diversified density (texture becoming more and less compressed), detachment of elements constituting orchestral texture, spatiality. We state that plastique of orchestral texture transpires in dialectical unity of opposites as it implies simultaneous unity of clarity, defined shape, relief, flexibility and "instability" (statics and process). As a principle of orchestral 
writing, plastique interacts with the principles of multi-figure composition and combinatorics. As the analysis of "Danses concertantes" and "Scunes de Ballet" shows, incarnations of plastique is done through a complex of codependent orchestral devices: flexibility of timbral dove-tailing of figures; active movement and rhythmically-intonational expressiveness of bass; usage of figures with different functions (figures of complex configuration, of movement in different directions, swirling, rounded ones); occasional "illuminating" duplication of lines; heterophonic splitting of lines forming the texture.

Key words: I. Stravinsky, plastique, terpsichorean, orchestral writing, orchestral texture, movement, spatiality, density.

Актуальність теми дослідження. Творчість І. Стравінського постійно перебуває у фокусі дослідницької думки, однак питання, пов'язані з оркестровим мисленням та письмом композитора, не так часто привертають увагу дослідників, висвітлюються фрагментарно, в контексті дотичної проблематики. Ми спробуємо поєднати два дослідницьких вектори: перший спрямований на пізнання специфіки оркестрового письма композитора, другий націлений на з'ясування природи та засобів виявлення пластичного начала, «пластичності» (яка загалом притаманна музиці І. Стравінського) в оркестровці на прикладі «Концертних танців». Зосередженість на оркестровому письмі композитора, проєкція пластичності на засоби оркестрового письма та залучення твору, який нечасто задіяний як аналітичний матеріал, становить актуальність нашої статті.

Різним питанням оркестровки I. Стравінського присвячені статті В. Гуркова [5], А. Шнітке [13], окремі аспекти висвітлені в монографіях А. Асаф'єва [2], М. Друскіна [6], С. Савенко [9]. Щодо виявлення пластичності (танцювальності, хоча ці поняття не $є$ тотожними) як якісної характеристики музики композитора можемо констатувати, що це питання також проартикульоване різними авторами 3 різною науковою інтенсивністю. М. Друскін наводить факт, що близько сорока симфонічних творів композитора отримали хореографічну інтерпретацію, підкреслюючи, що І. Стравінський до балету відчував особливу пристрасть; про це свідчить також і кількість створених ним балетних партитур [6, с. 73]. У балеті композитор знайшов умови для адекватної, всебічної реалізації іманентно властивої його музиці пластичності, яка походить від особливого відчуття часу (подієвого, пружного, інформаційна насиченість якого породжується нерегулярною непередбачуваною акцентністю) та простору (неоднорідного, 
багатоскладового, в якому поєднуються кілька зорових фокусів) [10]. У балеті рух, лінія, жест, пластика інтонаційно та темброво-фактурно об'єктивуються, отримують адекватне втілення у звукоматерії. Не випадково I. Вершинина пов'язує еволюцію композиторського мислення та злет майстерності I. Стравінського саме із досвідом роботи у сфері театральної (балетної) музики [4, с. 6].

Часто констатація наявності пластичності/танцювальності залишається авторами без розшифрування засобів, які сприяють їх формуванню, «виліпленню» в музичній, зокрема оркестровій тканині. Спробуємо здійснити це в нашій науковій розвідці.

У зв'язку з метою дослідження визначимося з поняттям «пластичності», міждисциплінарним за своєю природою. Не претендуючи на висвітлення загальної панорами наукових робіт з означеної проблеми, зауважимо, що вибраний авторами ракурс визначає більш або менш широке тлумачення цього поняття, тому згрупуємо джерела відповідним чином. У першій (філософсько-естетичній) групі пластичність інтерпретується як категорія, належна мисленню, свідомості. Так, О. Беспалов розуміє «пластичність» як універсалію художньої свідомості, що протиставляється «живописності» й виявляється в різних видах мистецтва. При цьому названі універсалії, на думку автора, є базовими, від них «походять» інші бінарні опозиційні пари: суб'єктивність - об'єктивність; замкнутість, кінцевість форми - відкритість, нескінченість; ясність - неясність мотиву; розчленування - єдність (розчиненість меж); предметність, понятійність - «атмосферичність»; статичність - рухливість та ін. [3]. Базова пара опозицій в аспекті філософського підходу є не тільки естетичними, а й культурологічними категоріями, які передують і простору художньої форми, і понятійності, матеріальності цього світу в цілому, «розташовуючись «поруч” 3 універсальним першопринципом, першопочатком» [3].

Інше розуміння категорії «пластичність» пропонує в дисертаційному дослідженні О. Струніва, де ця категорія осмислюється як іманентно властива людині якість, як світоглядна категорія, котра відбиває усунення природного та культурного протиріччя та інтегрує в собі різноманітні форми адаптації, що сприяють гармонізації відносин людини із собою та навколишнім світом. Як зауважує автор, «пластичність - це особлива гармонія, яка виявляється внутрішньо (гармонія із самою 
собою) і зовнішньо (гармонійні відносини з навколишньою дійсністю)» [12, с. 1]. У пластичності тут акцентується не оформленість і «скульптурність» - статичне начало, а гнучкість, «перехідність» - начало процесуальне. Процесуальність детермінується механізмом адаптації, яка відбувається в часі й завдяки гнучким функціональним переходам, перетворенням.

У другій групі праць поняття пластичності досліджується в площині певного виду мистецтва на конкретному матеріалі у музикознавчих працях -- присвячених балетному жанру. Так, С. Анфілова, досліджуючи еволюцію балету від XVII до XX ст. як інструмент пізнання й аналізу синтетичного цілого жанру, запроваджує діалектичні категорії «танцювальне-пластичне» й виявляє зв'язок цих категорій iз просторово-часовими, структурними й драматургійними закономірностями танцювальних спектаклів [1, с. 4]. Дослідниця вибудовує систему протиставлень «танцювального» та «пластичного». Втілення першого передбачає застосування «канонічних музично-хореографічних форм», «опору на конкретний танцювальний жанр (XV-XVIII століття) або риси дансантності: сувору періодичність, квадратність, ритмічну регулярність, акцентність, симетричність структури» [1, с. 6]. «Пластичне», на думку С. Анфілової, фокусувалось «в мімічних сценах “старого” балету», «не підкорялось суворим законам танцю», «Пов'язувалося 3 моментами творчої свободи танцюриста» $[1$, с. 6]. «"Пластичне” виявляється в тематичному розвитку, контрастності елементів, ритмічній нерегулярності, перевазі розвитку над експонуванням» [1, с. 6]. У проєкції на драматургію танцювальність та пластичність породжують діалектичне протиставлення статики та динаміки. «Танець, пов'язаний із демонстрацією техніки танцюриста, виключений із сюжетного розвитку, втілює циклічний час, зосереджуючи на внутрішній дії, підкреслюючи в музиці iii утилітарно-прикладну функцію. Мімічні сцени, рухаючи сюжет, проводять динамічний час, будучи виразником зовнішньої дії, а в музиці - процесуальності» [1, с. 6]. Така конотація пластичності певним чином корелює з розумінням пластичності в роботі О. Струнівої й утворює смислову опозицію розуміння «пластичності» в роботі О. Беспалова. Звернемо увагу на те, що О. Беспалов інтерпретує пластичність у смисловому зв'язку із «замкнутістю, кінцевістю форми», «ясністю», «розчленуванням», «статичністю» тощо, тобто 
вибудовує прямо протилежну систему смислових породжень порівняно із системою проєкцій «пластичного» в роботі С. Анфілової. У першому випадку у фокусі дослідницької уваги (з установкою на всеохоплення, високий рівень естетичних узагальнень і рух від загального до одиничного) перебувають візуально-пластичні види мистецтва, література та кіномистецтво, кожен із яких має свою специфіку, не враховану в роботі. У другому випадку власне музикознавчий підхід зумовив рух дослідницької думки від специфіки матеріалу до узагальнень на рівні універсальних категорій. Таким чином, із пропонованих тлумачень категорії «пластичності» у філософсько-естетичних та мистецтвознавчих роботах стає очевидним: єдиної точки зору на це питання не існує, що можна пояснити особливим ракурсом дослідження, рівнем узагальнень, але найбільше - тим аналітичним матеріалом, який осмислюється науковцем. Це наводить на думку про смислову полівалентність і діалектичність самого поняття, що зумовлює різновекторну його інтерпретацію.

У музикознавстві танцювальні жанри пов'язуються з пластичністю і в іншій площині. Т. Рибкіна вивчає питання пластичності в музиці з точки зору «взаємозв'язку звукового (ритмо-інтонаційного) плану вираження зі сферою пластичного відображення в процесі музичного сприйняття» [9, с. 4]. Автор спирається на вчення Б. Асаф'єва, застосовує запропоноване вченим поняття «ритмо-інтонація» через його звязок із пластичним досвідом людини [9, с. 3]. «Музичний образ у процесі сприйняття музики підсвідомо фіксується людиною як виразний жест, який своєю чергою є позазвуковим еквівалентом PI (ритмо-інтонації - $Г$. С. ), що зберігає іï енергію, спрямованість, просторові обриси» [9, с. 12]. Первинний рівень музичного сприйняття утворюють інтонаційні, моторно-рухові та просторово-часові стереотипи музичного сприйняття, стрижнем яких своєю чергою є певні комунікативні ситуації, що «тяжіють до давніх метасмислів» [9, с. 13]. «Найдавніші інтонаційні форми - протоінтонації - породжують у людині підсвідомі емоційні імпульси, які доповнюються моторно-пластичним малюнком і просторово-часовим образом, котрий асоціюється із ситуацією виконання та сприйняття» [9, с. 12]. I далі автор підсумовує, що «певна музична PI (ритмо-інтонація $-\Gamma$. C.) передбачає свій моторний еквівалент - певний образ руху, що народжується в межах кон- 
кретної емоційно-психологічної ситуації...» [9, с. 13]. Автор зауважує, що музика має власні засоби конкретизації образів - програму, жанр, стиль, національно-характерні риси музичної мови тощо [9, с. 13]. Для музикознавчого аналізу автор вибирає танцювальні жанри, пов'язані з «руховим каналом самовираження людини» [9, с. 13].

Як «міжвидову естетичну характеристику» й «механізм інтерпретації заявлених у програмі візуальних образів» розглядають пластичність Н. Коляденко та А. Шмелькова [7, с. 6]. У виявленні типології пластичності в музиці дослідники спираються на міжвидові загальні ознаки пластичності (чіткість, опуклість, явність, завершеність, оформленість, відчутність створюваного образу), які втілюються в музиці різними засобами. Дослідники виходять з ідеї синестетичності, вважаючи, що пластичність у музиці спирається на кінестетичні, моторно-рухові, просторові, жестові праобрази [7, с. 8]. Таким чином, ознаками пластичності в музиці, згідно з авторами, є: «1) чіткість, оформленість «звукового тіла», активізація візуальних параметрів його сприйняття; 2) об'ємність, опуклість, «скульптурність» звукового образу, що реалізується в музичному тексті через рельєфність, пластичне «проростання» фігури з фону; 3) автономність пластичного образу, його відмежованість <..> у музичному просторі; 4) можливість виявлення жестово-пластичних, тілесно-моторних ознак образів; 5) гравітаційні ознаки звукового тіла: щільність, «речовинність» музичної тканини; 6) активізація у сприйнятті синестетичних відчутних фактурних координат; 7) наявність, разом із процесуально-лінійними, «Просторових» зв'язків і відносин між окремими пластичними образами в музичному тексті й пов'язана з нею пульсація статики та динаміки <...> звукового простору» [7, с. 8-9]. Викладені положення, на нашу думку, можуть бути покладені в основу дослідження не тільки програмної музики, а й музики чистої, але виразно пластичної.

Підсумовуючи огляд наукової літератури, систематизуємо основні позиції стосовно поняття «пластичність»: 1) пластичність має різні конотації в широкій сфері гуманітарних досліджень, що детерміноване науковим методом, аналітичним матеріалом, метою досліджень (О. Беспалов; С. Анфілова); 2) «Пластичність» і «танцювальність» у музиці (на прикладі балету) є пов'язаними, але нетотожними поняттями 3 чітко 
окресленим колом засобів реалізації (С. Анфілова); 3) міжвидові загальні ознаки пластичності проєктуються в музиці через синестетичну єдність кінестетики, моторно-руховості, просторовості, жестовості в музичному просторі (Н. Коляденко, А. Шмелькова); 4) ритмо-інтонація може мати моторний еквівалент у вигляді образу руху, який відсилає до певних комунікативних ситуацій (Т. Рибкіна).

Зауважимо, що в жодній роботі параметр оркестровки не розглядається як засіб об’єктивації пластичності в музиці, зокрема у творах I Стравінського.

Мета дослідження полягає в систематизації оркестрових прийомів реалізації пластичності як однієї з універсалій оркестрового мислення I. Стравінського та принципу його оркестрового письма.

Наукова новизна роботи полягає в тому, що вперше в українському музикознавстві оркестрове письмо І. Стравінського досліджується в аспекті виявлення якісних характеристик пластичності й технічних прийомів його втілення.

Виклад основного матеріалу. Дослідники констатують, що i балетна (що цілком природно), і небалетна музика I. Стравінського проникнута особливою стихією танцю, танцювальністю в широкому смислі, не диференціюючи пластичність і танцювальність. М. Друскін наводить висловлювання самого композитора, де той пояснює своє тяжіння до балету, підкреслюючи домінування в класичному танці «вдумливої композиції над розпливчатістю», «правила над свавіллям», «порядку над випадковістю» [6, с. 73]. У такому розумінні йдеться саме про «танцювальність» (у трактуванні С. Анфілової) як підпорядкування жорстким правилам, яка в контексті висловлювань композитора набуває значення вищого естетичного принципу порядку, впорядкованості. Проте партитурам композитора притаманна і ясно відчутна пластичність. Під пластичністю будемо розуміти такі властивості оркестрової тканини, які, за Н. Коляденко та А. Шмельковою, активізують синестетичне сприйняття із задіянням візуальних та кінестетичних праобразів: формують виразні відчуття руху (різноспрямованого), об'єму (різновеликого і різнонаповненого), пластики ліній, різноякісної щільності (згущення-розрідження), відокремленості елементів оркестрової тканини, просторовості. Пластичність ми розуміємо діалектично - як ясність, оформленість, водночас гнучкість та «перехідність». 
Пластичність, на нашу думку, є однією 3 «універсалій» (термін С. Савенко [9]) оркестрового мислення I. Стравінського, взаємопов'язаною з іншими - багатофігурністю та комбінаторністю $[10 ; 11]$. У цьому зв'язку особливий інтерес становить теза О. Беспалова [3] щодо передування універсалій художній формі, яка, на думку автора, «комбінується 3 нескінченної множинності компонентів, серед яких виділяються універсалії, котрі існують ще немовби до форми й визначають «якість» інших, більш конкретних і речових складових форми» [3]. Ми висуваємо наукову гіпотезу, згідно 3 якою пластичність, багатофігурність та комбінаторність як взаємопов'язані універсалії оркестрового мислення I. Стравінського та принципи його оркестрового письма в різних жанрах втілюються в оркестровій тканині завдяки комплексу технічних прийомів оркестровки.

У своїй реалізації пластичність взаємодіє з принципом багатофігурності, адже пластичність виявляється в оркестровій тканині великою мірою завдяки застосуванню чітко окреслених фігур як елементів (одиниць) оркестрової тканини. Під фігурою в оркестровій тканині ми розуміємо відокремлену від інших у просторі, специфічно виділену одиницю оркестрової тканини. Засобами іiі виокремлення є чітка й графічна окресленість завдяки метро-ритмічному рішенню, мелодійному малюнку, тембровому втіленню (в чистих або мікстових тембрах), регістровому положенню. Ступінь іiі ритмо-інтонаційної індивідуальності, характерності простягається від майже «стертої» до значно виразної. Фігура може прозвучати однократно (доволі нечасто). Частіше фігури повторюються остинатно або варіантно-варіаційно. Фігури можуть належати до різних шарів оркестрової фактури, відповідно, є носіями різних оркестрових функцій.

Пластичність виявляється завдяки комплексу взаємопов'язаних прийомів оркестровки. У контексті нашої статті назвемо такі:

1) гнучкі темброві передачі фігур (однакових/різних), варіантів реалізації яких нескінченна множинність за різними параметрами: в мелодії / в інших оркестрових функціях, зі спільним тоном / без нього, односпрямовані/різноспрямовані, однократно проведені / багаторазово повторювані, у чистих тембрах / у тембрових мікстах, з відключенням тембрів після передачі / зі збереженням (див. «Концертні танці» ц. 10, ц. 23, 
ц. 53-56, 73-74,115-116 та ін.; «Балетні сцени» від ц. 5, ц. 19, ц. 27, ц. 44-46, ц. 62-63 та ін.). У реалізації тембрових передач часто задіяний принцип комбінаторності;

2) рухливий, ритмо-мелодійно виразний бас, конфігурація якого «грає» на відчуття об'єму, просторовості й одночасно легкості (чому слугує часто застосований прийом pizzicato). Басова функція вирішується І. Стравінським різнопланово: a) у традиційному октавному викладенні у віолончелей та контрабасів (див. «Концертні танці» від ц. 30); б) «розкиданою» між двома партіями в комплементарному ритмічному русі («Балетні сцени» ц. 28); в) у більш складній взаємодії 3 тембровими передачами й індивідуалізацією ритмічного профілю кожної партії («Балетні сцени» ц. 14). В останньому випадку щільність басової лінії є постійно змінюваною;

3) застосування фігур у різних шарах фактури як носіїв різних функцій: а) складної конфігурації; б) різноспрямованого руху; в) кружляння, обертання, закруглених (див. «Концертні танці» ц. 24, 27 (фігури кружляння, обертання), ц. 27, ц. 34, ц. 54, ц. 56 (втілення ідеї різноспрямованого руху); «Балетні сцени» ц. 26 та ц. 40 (еквіритмічні різноспрямовані фігури), ц. 44 та ц. 56 (темброві передачі різноспрямованих фігур), ц. 52 та ц. 64 (темброві передачі різноспрямованих фігур різноманітної конфігураціï)). Такі фігури створюють виразні кінестетичні та просторові відчуття завдяки своєму абрису, розмаху, ритмічному рішенню, яке уподібнює їх до витонченого розчерку пера, тембровому й регістровому втіленню, взаємодії з іншими фігурами. Особливу роль відіграють широкі фігураційні фігури в середніх голосах фактури. Створюючи розріджений простір, вони немовби розсувають звучання зсередини тканини (див. «Концертні танці» ц. 115-117; «Балетні сцени» ц. 14, ц. 19). Через апробацію різних фігур руху в широкому смислі здійснюється різноякісне наповнення простору, регулюється його щільність. Чергування епізодів, в основу яких покладені різні за конфігурацією фігури по горизонталі й вертикалі, стає чинником організації музичної драматургії та музичного часу.

Нерідко вся оркестрова тканина виявляється зітканою 3 фігур, прикладом чого може бути фрагмент партитури від ц. 58. Верхній шар фактури утворює партія першої флейти, яка спочатку ритмо-мелодійно взаємодіє з першою валторною за принципом комплементарності, а потім іiї партія насичується 
широкими фігурами спаду та злету. Партія валторни, що рухається довгими тривалостями, утворює другий шар фактури. Регістрово на них нашаровується фортепіано як третій тембровий пласт. Сильні долі фортепіанної партії дублюють довгі звуки валторни. Проте фактурно-ритмічний і мелодійний образ партії фортепіано суттєво відрізняється: його профіль визначає ритмо-фактурна формула (фігура) зі змінюваною звуковисотністю, «розкидана» в межах малої - третьої октав. Група струнно-смичкових інструментів без віолончелей і контрабасів утворює четвертий пласт, вирішений у щільному, але не тяжкому звучанні завдяки подвійним нотам і компактному розташуванню в межах першої-другої октав. Пластичність виявляється тут в органічному зв'язку оркестровими засобами (дублювання) графічно різних партій валторни та фортепіано, пластичній взаємодії валторни та флейти на основі комплементарності, промальовуванні простору розчерками флейтових фігур, створенні контрасту об'ємів між щільним звучанням групи струнно-смичкових і невагомим звучанням флейти. Характерно, що всі чотири темброві пласти оркестрової фактури регістрово нашаровуються один на оден, шо створює відчуття насиченості простору через складну мікстовість.

Пластична комплементарність виявляється й у складно організованихтемброво-фактурнихпластах, яківиконуютьсупровідно-фонову функцію. Прикладом може бути фрагмент партитури «Балетних сцен» від ц. 61, де поєднання елементів по вертикалі відбувається за принципом гнучкого «входження пазлів»;

4) фрагментарні дублювання-підсвітки, які гнучко під- та відключаються, регулюючи щільність простору і накреслюючи індивідуальний ритмічний і мелодійний рельєф ліній (див. «Концертні танці» ц. 4-1т.; «Балетні сцени» ц. 84). Цей прийом часто реалізується у взаємодії з принципом комбінаторності;

5) гетерофонне розщеплення ліній оркестрової фактури, що утворює відчуття об'єму, актуалізує візуальні графічні образи переплетіння (див. «Балетні сцени» ц. 15 та ц. 19 (гетерофонна взаємодія партій двох гобоїв)).

Висновки. Пластичність трактується нами як одна 3 «універсалій» (термін С. Савенко [9]) оркестрового мислення I. Стравінського (разом із багатофігурністю та комбінаторністю), а також як властивість (якісна характеристика) його оркестрового письма. На нашу думку, в оркестровій тканині пластичність виявляється в діалектичній єдності протилеж- 
ностей: вона передбачає одночасно ясність, оформленість, опуклість, гнучкість та «перехідність» (статичність та процесуальність). Аналіз партитур «Балетних сцен» $\mathrm{i}$ «Концертних танців» продемонстрував, що втілення пластичності відбувається завдяки комплексу взаємопов'язаних оркестрових прийомів: гнучкості тембрових передач фігур; рухливості, ритмо-мелодійній виразності басу; застосування різнофункціональних фігур (складної конфігурації, різноспрямованого руху, кружляння, обертання, закруглених); фрагментарному дублюванню-підсвітці, гетерофонному розщепленню ліній фактури.

Перспективами дослідження є виявлення дії пластичності в оперних та концертних партитурах, дослідження взаємодії пластичності з багатофігурністю та комбінаторністю як універсаліями оркестрового мислення І. Стравінського.

\section{СПИСОК ЛІТЕРАТУРИ}

1. Анфілова С. Співвідношення танцювального і пластичного в жанрі балету : автореф. дис. ... канд. мистецтв. : 17.00.03 «Музичне мистецтво» / Харківський державний університет мистецтв імені І.П. котляревського. Харків, 2005. 18 с.

2. Асафьєв Б. Книга о Стравинском. Ленинград : Музыка, 1977. $279 \mathrm{c}$.

3. Беспалов О.В. Пластичность и живописность как универсалии художественного сознания : дис. ... канд. философ. наук : 09.00.04 «Эстетика» / Государственный институт искусствознания. Москва, 1999. 148 c. URL: https://www.dissercat.com/content/plastichnost-izhivopisnost-kak-universalii-khudozhestvennogo-soznaniya.

4. Вершинина И. Ранние балеты Стравинского. Москва : Наука, 1967. 222 c.

5. Гурков В. Оркестровые принципы и ладовое мышление И. Стравинского (на примере «Весны священной»). Оркестровые стили в русской музыке. Ленинград : Музыка, 1987. С. 82-94.

6. Друскин М. Игорь Стравинский. Личность, творчество, взгляды. Исследование. Ленинград : Советский Композитор, 1982. 208 с.

7. Коляденко Н., Шмелькова А. Пластичность как общеэстетическое и музыкальное явление. Вестник музыкальной науки. 2013. C. 5-11. URL: https://cyberleninka.ru/article/n/plastichnost-kakobscheesteticheskoe-i-muzykalnoe-yavlenie/viewer.

8. Рыбкина Т.В. Музыкальное восприятие: пластические образы ритмо-интонации в свете учения Б. Асафьева : автореф. дис. ... канд. искусств. : 17.00 .02 «Музыкальное искусство» / Магнитогорская государственная консерватория имени М. Глинки. Магнитогорск, 2004. $24 \mathrm{c}$.

9. Савенко С. Мир Стравинского. Москва : Композитор, 2001. 327 c. 
10. Савченко Г.С. Багатофігурність оркестрового письма як принцип організації часу і простору в оркестрових творах І.Ф. Стравінського (від ранніх балетів до Симфонії in $\mathrm{C}$ та Симфонії у трьох частинах). Аспекти історичного музикознавства. 2019. Вып. 16. C. 242-258. doi: 10.34064/khnum2-1614.

11. Савченко Г.С. Комбінаторність як принцип оркестрового мислення І.Ф. Стравінського. Культура та мистецтво: сучасні тенденції та перспективи: матеріали Всеукраїнської науково-практичної конферениії. Одеса, 2020. С. 281-283.

12. Струнива Е.Н. Пластичность как форма реализации культуры личности : автореф. дис. ... канд. философ. наук : 24.00.01 «Теория и история культуры» / Нижегородский государственный архитектурностроительный университет. Нижний Новгород, 2004. 32 с.

13. Шнитке А. Особенности оркестрового голосоведения ранних произведений Стравинского. Музыка и современность. 1967. Вып. 5. C. 209-261.

\section{REFERENCES}

1. Anfilova, S. (2005). Spivvidnoshennya tantsyuvalnogo i plastichnogo $\mathrm{v}$ zhanri baletu [The ratio of dance and plastic in the genre of ballet]. (Extended abstract of $\mathrm{PhD}$ thesis). Kharkiv State University of Arts named after IP Kotlyarevsky. Kharkiv, 18 p. [In Ukrainian].

2. Asaf'ev, B. (1977). Kniga pro Stravinskogo [Book of Stravinsky]. Leningrad : Muzyka, 279 p. [In Russian].

3. Bespalov, O.V. (1999). Plastychnost y zhyvopysnost kak unyversalyy khudozhestvennoho soznanyia [Plasticity and picturesqueness as universals of artistic consciousness]. (PhD dissertation). State Institute of Art History. Moscow, 148. URL: https://www.dissercat.com/content/ plastichnost-i-zhivopisnost-kak-universalii-khudozhestvennogo-soznaniya [In Russian].

4. Gurkov, V. (1987). Orkestrovyie printsipyi i ladovoe myishlenie I. Stravinskogo (na primere «Vesnyi svyaschennoy») [Orchestral Principles and the Mode of Thinking of I. Stravinsky (on the example of the "Sacred Spring")]. Orchestral styles in Russian music, pp. 82-94 [In Russian].

5. Vershinina, I. (1967). Rannie balety' Stravinskogo [Stravinsky' early ballets]. Moscow : Nauka, 222 p. [in Russian].

6. Druskin, M. (1982). Igor' Stravinskij. Lichnost', tvorchestvo, vzglyady`. Issledovanie. [Igor Stravinsky. Personality, creativity, views. Study.]. Leningrad : Sovetskij Kompozitor, 208 p. [in Russian].

7. Koliadenko, N., Shmelkova, A. (2013). Plastychnost kak obshcheestetycheskoe i muzykalnoe yavlenye [Plasticity as a general aesthetic and musical phenomenon]. Bulletin of music science, 5-11. URL: https://cyberleninka.ru/article/n/plastichnost-kak-obscheesteticheskoe-i-muzykalnoe-yavlenie/viewer [In Russian].

8. Rybkyna, T.V. (2004). Muzykalnoe vospryiatye: plastycheskye obrazy rytmo-yntonatsyy $v$ svete uchenyia B. Asafeva [Rybkina TV Musical perception: plastic images of rhythmic intonation in the light 
of B. Asafyev`s teachings]. (Extended abstract of $\mathrm{PhD}$ thesis). Magnitogorsk State Conservatory named after M. Glinka. Magnitogorsk, 24 p. [In Russian].

9. Savenko, S. (2001). Mir Stravinskogo [Stravinsky's World]. Moscow: Kompozitor, 327 p. [In Russian].

10. Savchenko, H.S. (2019). Bahatofihurnist orkestrovoho pysma yak pryntsyp orhanizatsii chasu i prostoru v orkestrovykh tvorakh I.F. Stravinskoho (vid rannikh baletiv do Symfonii in $\mathrm{C}$ ta Symfonii u trokh chastynakh) [Orchestral composition multifigure as a principle of time and space organization of Ihor F. Stravinsky's orchestral works (from early ballets to Symphony in C and Symphony in three movements)]. Aspects of historical musicology, 16, pp. 242-258 [In Ukrainian]. doi: 10.34064/ khnum2-1614.

11. Savchenko, H.S. (2020). Kombinatornist yak pryntsyp orkestrovoho myslennia I.F. Stravinskoho [Combinatorics as a principle of orchestral thinking of I.F. Stravinsky]. Culture and art: current trends and prospects: materials of the All Ukrainian scientific-practical conference. Odessa. Pp. 281-283 [In Ukrainian].

12. Strunyva, E.N. (2004). Plastychnost kak forma realyzatsyy kultury lychnosty [Plasticity as a form of realization of personality culture]. (Extended abstract of PhD thesis). Nizhny Novgorod State University of Architecture and Civil Engineering. Nizhniy Novgorod, 32 p. [In Russian].

13. Shnitke, A. (1967). Osobennosti orkestrovogo golosovedeniya rannih proizvedeniy Stravinskogo [Features of the orchestral voice of the early works of Stravinsky]. Music and Modernity, 5, pp. 209-261 [In Russian]. 